\title{
HIV Mobile Clinic as a Part of the Comprehensive Social and Public Health Program in the Malindi Coastal Area
}

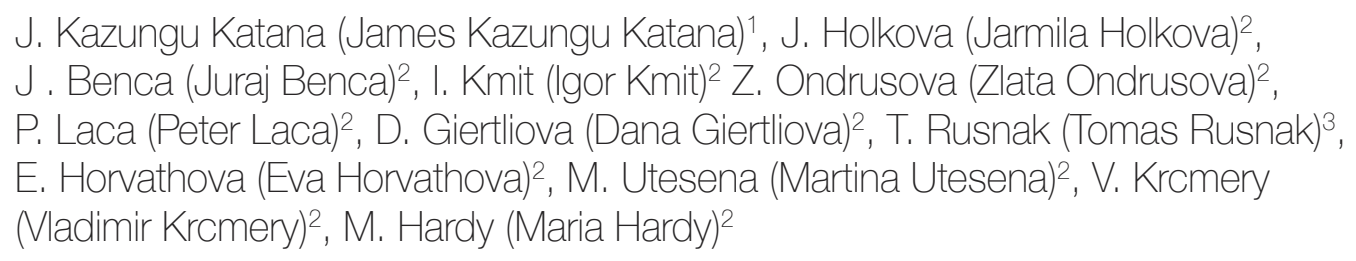

${ }^{1}$ Ushirikiano Centre SEU Tropical Program Malindi, Kenya.

${ }^{2}$ Slovak Tropical Institute Dept. Tropical Disease SEU and

Slovak Medical University school of Medicine and School of Public Health, Slovakia.

${ }^{3}$ St. Philip Neri rescue center Kisumu, Kenya.

\section{E-mail address:}

jimmy.katana.big1@gmail.com

\section{Reprint address:}

James Kazungu Katana

Ushirikiano Centre, St. Mary's Catholic Mission

Msabaha, P.O. Box 256,

80200 Malindi

Kenya

Source: Clinical Social Work and Health Intervention

Volume: 12

Issue: 1

Pages: $15-16$

Cited references: 3

\section{Reviewers:}

Daria Kimuli

Catholic University of Eastern Africa, Nairobi, Kenya

Lesley Bucko

Phnom Phen, Cambodia

\section{Keywords:}

HIV. Screening.

\section{Publisher:}

International Society of Applied Preventive Medicine i-gap

CSWHI 2021; 12(1): 15 - 16; DOI: 10.22359/cswhi_12_1_02 (C) Clinical Social Work and Health Intervention

\section{Abstract:}

The Unshurikian Center is one of the classical examples of a social and health related joint venture suitable for sub-Saharan Africa focused on social work with poor families; support of children from low income families to visit school; outpatient services for basic diseases in the coastal area; and HIV Outreach Program running for 12 years. 


\section{Introduction}

The coastal area of Kenya is full of social and health care contrasts such as modern first class hotels for EU tourists neighboring with poor rural satellites and villages. The aim of this short communication is to underline the screening for HIV in this area famous for sexually transmitted diseases due to tourism and extreme poverty helping many families to survive despite the huge risk acquiring STD including HIV and hepatitis C within last 20 years which may be a real threat not only for dissemination of HIV but also other related STD diseases having consequences for families and demographic adverse outcomes.

\section{Methods and setting}

The Malindi area has about 100,000 inhabitants and about 10,000 tourists mainly from Italy and other EU countries close to another resort area of Mombasa and historical Lamu. Mombasa is visited weekly with about 20.000 tourists for sports, sea activities and history. But Malindi is famous by sex tourism and first class beach hotels. However, neighborhoods of Malindi include areas affected with extreme poverty. Therefore, a part of Ushurikiano comprehensive educational school and anti-malnutrition program, also conduct screening for HIV by active surveillance performed twice a month by our staff.

\section{Results and discussion}

The number of clients for active social work reaches $80-100$ weekly in adults and up to 200 children, the commonest social pathology and aims of social work include items in Table 1:

\section{Table I.}

Reasons for social work and commonest social pathology Ushurikiano Malindi

1. poverty and lack of proper nutrition 80-100 families, up to $100 \%$ of visits

2. need for educational support 135 children

3. substance and alcohol abuse $20 \%$

4. domestic violence $21 \%$

5. CAN $13 \%$

6. prostitution $7 \%$

7. crime $3.5 \%$

8. HIV prevalence $5-10 \%$

HIV mobile testing with the rapid test is performed once monthly for $50-60 \%$, and this num- ber as well as the proportion of positives is relatively stable and decreased from 10-15\% 20 years ago to $5-10 \%$ nowadays, also due to the decreasing number of sex tourists after kidnappings in Lamu and terrorist attacks in Mombasan hotels with tourists from Israel 10 years ago.

\section{Conclusions}

Active surveillance for HIV and TB is important in all touristic centers in coastal Eastern Africa, including Muslim areas of Pemba Zanzibar and Tanzania, since most of the STD,s are imported. Prostitution has economic rates and economic consequences and is also related to lower education. Therefore, major strategic plans for this area is

a. to support to bring the children from household and poverty to school and support the education

b. ensure improved nutrition supporting small business in families and assist single mothers

c. continue with 10 years history of active surveillance of HIV at least on a monthly basis which is a part of HIV may diagnose also related STD and TB

\section{References}

1. WHO ANNUAL REPORT - SUB-SAHARAN AFRICA (2017) World health Organisation Genève, 2017. 265 pp.

2. PLACKOVA A, ONDREICKOVA A (2019) Pain - importance for rehabilitation, Rehabilitation, Vol 56, No 4, 2019, ISSN 0375-0922, s.21-40.

3. UNITED NATIONS AIDS PROGRAM (2015) UN New York, UN publishing House, 2015. 145 pp. 